ISSN 1678-3921

Journal homepage: www.embrapa.br/pab

For manuscript submission and journal contents, access: www.scielo.br/pab

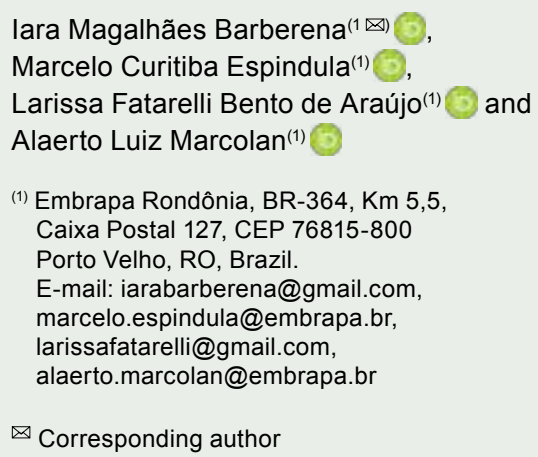

\section{Use of urease inhibitors to reduce ammonia volatilization in Amazonian soils}

\begin{abstract}
The objective of this work was to evaluate urease inhibitors for the reduction of ammonia volatilization in Amazonian soils. The work was carried out on a clayey yellow Oxisol, a clayey red Oxisol, and on a light silty Ultisol. Each experiment was conducted in split plots, using standard urea, urea $+\mathrm{a}$ benzimidazole-type urease inhibitor (BZI1), urea + a benzoylthiourea-type urease inhibitor (RTB68), urea $+N$-(n-butyl) triamide thiophosphate (NBPT), or a fertilizer-free control. Volatilized ammonia was collected at 48, 96, 144, 192, 240, 288, 336, and 384 hours after fertilization. Ammonia volatilization reached a maximum at 144 hours in the urea, urea + benzimidazole, and urea + benzoylthiourea treatments. A peak level was reached at 192 and 288 hours in the urea $+N$ - $(n$-butyl) triamide thiophosphate treatment. In yellow Oxisols, benzimidazole and benzoylthiourea reduced the ammonia losses by 22 and $10 \%$, respectively, in soils without urease inhibitors. However, neither of these agents significantly reduced ammonia volatilization at the rate determined for standard urea in red Oxisols or Ultisols. $N$-( $n$-butyl) triamide thiophosphate is the most efficient urease inhibitor for the soils of southwestern Amazonia.
\end{abstract}

Index terms: benzimidazole, benzoylthiourea, Oxisol, Plinthosol, urease inhibitors.

\section{Uso de inibidores de urease para reduzir a volatilização de amônia em solos amazônicos}

Resumo - O objetivo deste trabalho foi avaliar inibidores de urease quanto à redução de perdas por volatilização de amônia proveniente da ureia, em solos da Amazônia. O experimento foi realizado em um Latossolo Amarelo de textura muito argilosa, em um Latossolo Vermelho de textura argilosa, e em um Plintossolo Argilúvico de textura franco-siltosa. Cada experimento foi realizado em arranjo de parcelas subdivididas no tempo, com uso de ureia convencional, ureia + benzimidazol, ureia + benzoiltioureia, ureia $+N$-( $n$-butil) triamida trifosfato, e um controle sem fertilizante. A amônia volatilizada foi coletada 48, 96, 144, 192, 240, 288, 336 e 384 horas após aplicação dos fertilizantes. Os picos de volatilização de amônia atingiram o máximo às 144 horas nos tratamentos com ureia convencional, ureia + benzimidazol e ureia + benzoiltioureia. Picos de volatilização entre 192 e 288 horas ocorreram no tratamento ureia $+N$-( $n$-butil) triamida trifosfato. Em Latossolo Amarelo, os compostos benzimidazol e o benzoiltioureia promoveram redução de 22 e $10 \%$, respectivamente, das perdas de amônia, em solos sem inibidores de urease. No entanto, nenhum desses agentes reduziu significativamente a volatilização da amônia à taxa determinada para ureia convencional, em Latossolo Vermelho e em Plintossolo Argilúvico. $N$-( $n$-butil) triamida trifosfato é o inibidor de urease mais eficiente para os solos do sudoeste da Amazônia.

Termos para indexação: benzimidazol, benzoiltioureias, Latossolo, Plintossolo, inibidores de urease. 


\section{Introduction}

Urea is the most widely used nitrogen fertilizer worldwide (IFASTAT, 2019). However, it is susceptible to ammonia volatilization which constitutes a loss of nitrogen. This process occurs more frequently and is more severe in tropical countries like Brazil (Frazão et al., 2014). Wind speed, temperature (Rochette et al., 2009), relative air humidity (Silva et al., 2017), and rainfall (Afshar et al., 2018) all contribute to ammonia volatilization.

The nitrogen losses associated with ammonia volatilization are also influenced by cation exchange capacity (Costa et al., 2004), humidity (Tasca et al., 2011), temperature (Da Ros et al., 2005), organic matter content (Knoblauch et al., 2012), pH (Sommer et al., 2004), and ammonium concentration (Rochette et al., 2009).

Natural and synthetic soil-urease inhibitors have been investigated to reduce ammonia volatilization. The urease inhibitor most commonly used with fertilizers is $N$-(n-butyl) triamide thiophosphate (NBPT) (Mathialagan et al., 2017). When it is mixed with urea, it delays the hydrolysis and improves the incorporation of nitrogen into the soil. However, it is easily degraded during handling and storage (Sutton \& Thornsberry, 2007).

Identifying urease inhibitors that are chemically stable, potent, compatible with urea, cheap, and nontoxic to plants, is challenging (Modolo et al., 2015). Substances which meet all these criteria include benzoylthioureas and benzimidazoles.

Benzoylthioureas (BTUs) contain the well-known, commercially available urease inhibitor thiourea. They are stable during storage and transport. In these respects, they are superior to NBPT (Brito et al., 2015). Benzimidazole derivatives are also potent urease inhibitors (Santosh et al., 2011). They effectively reduce the enzymatic activity in disease occurrences. New benzimidazole derivatives have been synthesized and tested on soil ureases.

Exploratory-phase studies with BTUs (Brito et al., 2015) and benzimidazoles (Araújo, 2015), in both laboratory and field conditions, have produced promising results. Therefore, it is necessary to test and elucidate their efficacies against soil ureases.
The objective of this work was to evaluate urease inhibitors in the reduction of ammonia volatilization in Amazonian soils.

\section{Materials and Methods}

The experiment was carried out at the experimental station of Embrapa Rondônia ( $8^{\circ} 48^{\prime} 11^{\prime \prime S}$ and 63050'58" W), in the municipality of Porto Velho, in the state of Rondônia, Brazil, between June 17, 2016 and July 2, 2016. Maximum and minimum temperature and relative air humidity $(\mathrm{RH})$ data were collected every 24 hour using a digital thermo-hygrometer with temperature and $\mathrm{RH}$ precisions of $\pm 1^{\circ} \mathrm{C}$ and $\pm 5 \%$, respectively (Figure 1).

The experiment was performed in the following soil types: Latossolo Amarelo, a dystrophic clayey yellow Oxisols (YOs); Latossolo Vermelho, a clayey eutrophic red Oxisols (ROs); and Plintossolo Argilúvico, a finesilty dystrophic Ultisols (ULs) (Santos et al., 2013). The YOs were collected in the fallow area of the experimental field of Embrapa in the municipality of Machadinho do Oeste $\left(9^{\circ} 23^{\prime} 49^{\prime \prime} \mathrm{S}\right.$ and $\left.62^{\circ} 01^{\prime} 15^{\prime \prime} \mathrm{W}\right)$. The ROs were collected in the municipality of Alta Floresta d'Oeste $\left(12^{\circ} 05^{\prime} 02^{\prime \prime} \mathrm{S}\right.$ and $\left.62^{\circ} 02^{\prime} 59^{\prime \prime} \mathrm{W}\right)$ in the inter-rows of one-year-old coffee orchards (Coffea canephora). The crop area had been cultivated with this coffee species for 10 years. The ULs were collected in the pasture area of the experimental field of Embrapa in the municipality of Porto Velho $\left(8^{\circ} 53^{\prime} 20^{\prime \prime} \mathrm{S}\right.$ and $\left.63^{\circ} 06^{\prime} 40^{\prime \prime} \mathrm{W}\right)$. Disturbed and air-dried soil samples were analyzed at the laboratory of soil analysis of Instituto Capixaba de Pesquisa, Assistência Técnica e Extensão Rural (Incaper) in the municipality of Linhares, in the state of Espírito Santo, Brazil (Table 1).

The experimental design consisted of split plot with five $\mathrm{N}$ sources and eight volatilized ammonia collection time points. The $\mathrm{N}$ sources were: standard urea (SU) (Merck); urea + the gold standard urease inhibitor $N$-(n-butyl) thiophosphoric triamide (NBPT) (Agrotain); urea + benzimidazole urease inhibitor BZI1 (Figure 2); urea + benzoylthiourea inhibitor RTB68 (Figure 2); and an untreated, unfertilized control area. All treatments provided $45 \%$ nitrogen. The volatilized ammonia collection time points were $48,96,144,192$, $240,288,336$, and 384 hours after fertilization. The experimental design was completely randomized with five replicates. The experimental plots consisted of 
$8 \mathrm{dm}^{-3}$ polyethylene pots containing $9 \mathrm{~kg}$ soil each. Before fertilization, sufficient water was added to each pot to reproduce $100 \%$ field capacity for each soil type. No further irrigation was conducted during the experiment.

Urease inhibitors were selected on the basis of data obtained from the Network for the Development of Novel Urease Inhibitors (REDNIU). One hundred milligrams of each inhibitor was dissolved in $3.0 \mathrm{~mL}$ solvent for every $10 \mathrm{~g}$ urea. Acetone solubilized the BZI1 and dichloromethane solubilized the RTB68.

Volatilized ammonia was collected with a semiopen, static-free collection chamber consisting of transparent $2 \mathrm{~L}$ polyethylene terephthalate bottles with a surface area of $\sim 0.008 \mathrm{~m}^{2}$ (Araújo et al., 2009).

Fertilization was simulated using $400 \mathrm{~kg} \mathrm{ha}^{-1} \mathrm{~N}$ per year, divided into five applications. Therefore, $80 \mathrm{~kg}$ $\mathrm{ha}^{-1} \mathrm{~N}$ per application was distributed on 1,666 plants which amounted to $48 \mathrm{~g} \mathrm{~N}$ per plant per application. Since this amount of $\mathrm{N}$ was applied to a $1 \mathrm{~m}^{2}$ coffeeorchard area, $0.384 \mathrm{~g} \mathrm{~N}$ per collector was used. Fertilizers were weighed on a precision analytical scale, and they were manually applied to the soil within the ammonia collector circumference.

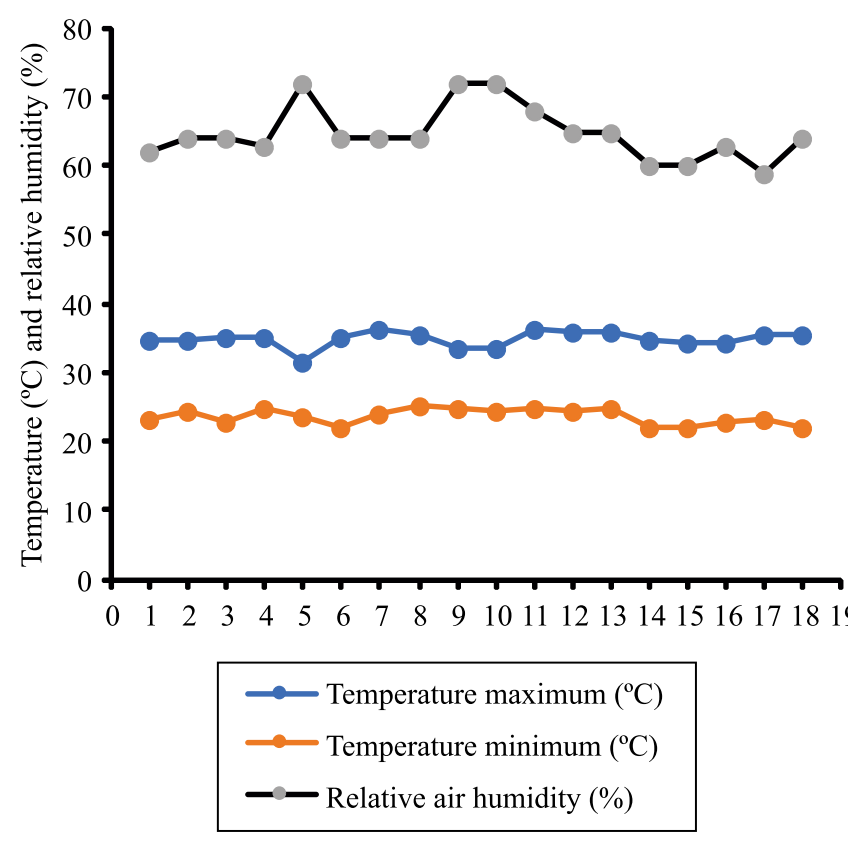

Figure 1. Maximum and minimum temperatures, and relative air humidity, in the period from June 17 to July 02, in the municipality of Porto Velho, in the state of Rondônia, Brazil, 2016.
The collection chamber was installed on the soil surface immediately after fertilization. The ammonia collection system foams were replaced every 48 hours

Table 1. Physicochemical properties of the soils in Rondônia, Brazil.

\begin{tabular}{|c|c|c|c|}
\hline Soil properties & yellow Oxisol & red Oxisol & Ultisol \\
\hline $\mathrm{pH}\left(\right.$ in $\left.\mathrm{H}_{2} \mathrm{O}\right)$ & 4.2 & 5.8 & 4.8 \\
\hline $\mathrm{OM}\left(\operatorname{dag} \mathrm{kg}^{-1}\right)$ & 2.05 & 3.19 & 2.06 \\
\hline $\mathrm{P}\left(\mathrm{mg} \mathrm{dm}^{-3}\right)$ & 3.0 & 12.9 & 2.4 \\
\hline $\mathrm{K}\left(\mathrm{mg} \mathrm{dm}{ }^{-3}\right)$ & 44.0 & 89.0 & 44.0 \\
\hline $\mathrm{Na}\left(\mathrm{mg} \mathrm{dm}^{-3}\right)$ & 3.0 & 2.0 & 2.0 \\
\hline $\mathrm{Ca}^{2+}\left(\mathrm{cmol}_{\mathrm{c}} \mathrm{dm}^{-3}\right)$ & 0.67 & 9.53 & 1.2 \\
\hline $\mathrm{Mg}^{2+}\left(\mathrm{cmol}_{\mathrm{c}} \mathrm{dm}^{-3}\right)$ & 0.15 & 1.56 & 0.17 \\
\hline $\mathrm{Al}^{+3}\left(\mathrm{cmol}_{\mathrm{c}} \mathrm{dm}^{-3}\right)$ & 1.75 & 0.0 & 1.75 \\
\hline $\mathrm{H}^{+}+\mathrm{Al}^{3+}\left(\mathrm{cmol}_{\mathrm{c}} \mathrm{dm}^{-3}\right)$ & 8.8 & 3.2 & 7.9 \\
\hline SEB & 0.94 & 11.33 & 1.49 \\
\hline ECEC & 2.69 & 11.33 & 3.24 \\
\hline CEC & 9.74 & 14.53 & 9.39 \\
\hline BS & 9.7 & 78.0 & 15.9 \\
\hline $\mathrm{m}(\%)$ & 65.1 & 0.0 & 54 \\
\hline $\mathrm{Na}$ (saturation index) & 0.48 & 0.08 & 0.27 \\
\hline $\mathrm{Zn}\left(\mathrm{mg} \mathrm{dm}{ }^{-3}\right)$ & 0.6 & 4.7 & 0.6 \\
\hline $\mathrm{Fe}\left(\mathrm{mg} \mathrm{dm}^{-3}\right)$ & 123.3 & 19.6 & 269.9 \\
\hline $\operatorname{Mn}\left(\mathrm{mg} \mathrm{dm}^{-3}\right)$ & 4.6 & 153.6 & 1.2 \\
\hline $\mathrm{Cu}\left(\mathrm{mg} \mathrm{dm}^{-3}\right)$ & 0.47 & 2.52 & 0.45 \\
\hline $\mathrm{B}\left(\mathrm{mg} \mathrm{dm} \mathrm{m}^{-3}\right)$ & 1.1 & 0.6 & 0.4 \\
\hline Bulk density $\left(\mathrm{g} \mathrm{cm}^{-3}\right)$ & 1.1 & 1.2 & 1.2 \\
\hline \multicolumn{4}{|l|}{ Pressure $(\mathrm{kPa})$} \\
\hline $10^{(1)}$ & 30.73 & 29.7 & 18.37 \\
\hline $1500^{(2)}$ & 27.02 & 23.4 & 12.08 \\
\hline \multicolumn{4}{|l|}{ Granulometry } \\
\hline Coarse sand $\left(\mathrm{g} \mathrm{kg}^{-1}\right)$ & 38 & 25 & 16.2 \\
\hline Fine sand $\left(\mathrm{g} \mathrm{kg}^{-1}\right)$ & 27 & 150 & 180.4 \\
\hline Silt $\left(\mathrm{g} \mathrm{kg}^{-1}\right)$ & 91 & 361 & 579.4 \\
\hline Clay $\left(\mathrm{g} \mathrm{kg}^{-1}\right)$ & 844 & 464 & 224 \\
\hline
\end{tabular}

SEB, sum of exchangeable bases; ECEC, effective cation exchange capability; CEC, cation exchange capacity at $\mathrm{pH}$ 7.0; BS, base saturation; $\mathrm{m}$, aluminum saturation; OM, organic matter. ${ }^{(1)}$ Field capacity. ${ }^{(2)}$ Wilting point. ${ }^{(3)}$ Water mass per soil mass.

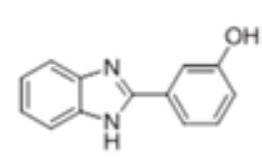

BZI1

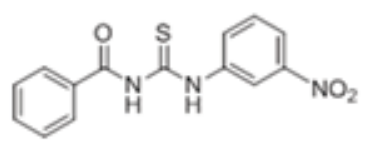

RTB68
Figure 2. Molecular draft of the urease inhibitor organic compounds tested. 
until 384 hours after fertilization. They were analyzed in the laboratory of soils and plants of Embrapa Rondônia. The amount of volatilized ammonia in the foams was determined with a Kjeldahl-type steam distiller. The extracts were titrated to quantify ammonia nitrogen (Araújo et al., 2009).

All data were subjected to the analysis of variance, at $5 \%$ probability. There was a significant interaction effect between the nitrogen sources and the time after fertilization. Therefore, factor analysis was performed. The Scott-Knott test grouped the mean nitrogen quantities at each time point, at $5 \%$ probability. The time of fertilization effect was determined by selecting regression curves based on the best fit models, which were defined by the highest coefficients of determination and significance levels for the equation coefficients. The regressions were fitted in SigmaPlot v. 10 (Systat Software, Inc., San Jose, CA, USA).

\section{Results and Discussion}

Ammonia volatilization in all treatments in the YOs was similar to that of the untreated control in the first 48 hours. The lack of any significant post-fertilization ammonia loss may be explained by the abundance of hydrogen ions $\left(\mathrm{H}^{+}\right)(\mathrm{pH} 4.2)$ and the high $\mathrm{H}+\mathrm{Al}$ concentration $\left(8.8 \mathrm{cmol}_{\mathrm{c}} \mathrm{dm}^{-3}\right)$. Hydrogen ions react with ammonia to form nonvolatile ammonium cation $\left(\mathrm{NH}_{4}^{+}\right)($Cantarella, 2007).
The $100 \%$ field capacity at fertilization may have influenced urea movement in the YOs (Table 1). Available urea was hydrolyzed below the surface, which minimized ammonia volatilization losses (Duarte et al., 2007). Other studies have also reported the reduction of ammonia volatilization by high-soil moisture. Nitrogen losses due to ammonia volatilization were $31.5 \%$ lower in well-hydrated Haplic Planosols than in comparatively drier soils (Scivittaro et al., 2010). Maintaining soil moisture at 50\% field capacity promoted fertilizer incorporation within the first days after application (Gurgel et al., 2016).

In all YO treatments, at 96 hours after fertilization, urea + RTB68 and urea without urease inhibitor showed the highest-ammonia losses. The descending order of ammonia volatilization was: $\mathrm{SU}=$ urea + RTB68 $>$ urea + BZ11 $>$ urea + NBPT $=$ untreated control (Table 2). Beyond 48 hours after fertilization, the $\mathrm{pH}$ may have increased near the urea granules because the reaction forming ammonium consumes $\mathrm{H}^{+}$and increases soil pH (Rochette et al., 2009). Variations in ammonia volatilization as a function of soil $\mathrm{pH}$ were reported for Humic Cambisols fertilized with urea and with urea + NBPT (Tasca et al., 2011).

The high-ammonia volatilization measured for RTB68 corroborated a previous report, in which jack bean urease had low efficacy in vitro (Brito et al., 2015). In contrast, the results of the present work do

Table 2. Nitrogen losses due to ammonia volatilization at 384 hours after nitrogen fertilization in three Amazonian soils ${ }^{(1)}$.

\begin{tabular}{|c|c|c|c|c|c|c|c|c|c|c|}
\hline \multirow[t]{2}{*}{ Soil type } & \multirow[t]{2}{*}{ Nitrogen source } & \multicolumn{9}{|c|}{ Ammonia loss $\left(\mathrm{kg} \mathrm{ha}^{-1}\right)$} \\
\hline & & $48 \mathrm{~h}$ & $96 \mathrm{~h}$ & $144 \mathrm{~h}$ & $192 \mathrm{~h}$ & $240 \mathrm{~h}$ & $288 \mathrm{~h}$ & $336 \mathrm{~h}$ & $384 \mathrm{~h}$ & Accumulated \\
\hline \multirow{5}{*}{$\begin{array}{l}\text { Yellow } \\
\text { Oxisol (YO) }\end{array}$} & Standard urea & $0.06 \mathrm{a}$ & $6.30 \mathrm{a}$ & $9.13 \mathrm{a}$ & $2.30 \mathrm{a}$ & $0.88 \mathrm{a}$ & $0.55 b$ & $0.30 \mathrm{a}$ & $0.25 \mathrm{a}$ & $19.77 \mathrm{a}$ \\
\hline & Urea + BZI1 & $0.05 \mathrm{a}$ & $3.10 \mathrm{~b}$ & $7.80 \mathrm{~b}$ & $2.32 \mathrm{a}$ & $0.88 \mathrm{a}$ & $0.64 b$ & $0.32 \mathrm{a}$ & $0.27 \mathrm{a}$ & $15.37 \mathrm{c}$ \\
\hline & Urea + RTB68 & $0.01 \mathrm{a}$ & $5.98 \mathrm{a}$ & $7.99 b$ & $2.03 \mathrm{a}$ & $0.80 \mathrm{a}$ & $0.56 b$ & $0.24 \mathrm{a}$ & $0.28 \mathrm{a}$ & $17.85 b$ \\
\hline & Urea + NBPT & $0.04 \mathrm{a}$ & $0.00 \mathrm{c}$ & $0.05 \mathrm{c}$ & $0.22 b$ & $0.54 \mathrm{a}$ & $1.25 \mathrm{a}$ & $0.99 \mathrm{a}$ & $0.57 \mathrm{a}$ & $3.58 \mathrm{~d}$ \\
\hline & $0 \%$ nitrogen & $0.04 \mathrm{a}$ & $0.00 \mathrm{c}$ & $0.02 \mathrm{c}$ & $0.00 \mathrm{~b}$ & $0.00 \mathrm{~b}$ & $0.00 \mathrm{~b}$ & $0.00 \mathrm{a}$ & $0.02 \mathrm{a}$ & $0.08 \mathrm{e}$ \\
\hline \multirow{5}{*}{$\begin{array}{l}\text { Red } \\
\text { Oxisol (RO) }\end{array}$} & Standard urea & $6.29 \mathrm{a}$ & $10.59 \mathrm{~b}$ & $3.11 \mathrm{a}$ & $1.42 \mathrm{a}$ & $0.95 \mathrm{a}$ & $0.48 \mathrm{a}$ & $0.32 \mathrm{a}$ & $0.25 \mathrm{a}$ & $23.41 \mathrm{a}$ \\
\hline & Urea + BZI1 & $3.86 \mathrm{~b}$ & $11.95 \mathrm{a}$ & $2.99 \mathrm{a}$ & $1.59 \mathrm{a}$ & $0.88 \mathrm{a}$ & $0.55 \mathrm{a}$ & $0.35 \mathrm{a}$ & $0.24 \mathrm{a}$ & $22.42 \mathrm{a}$ \\
\hline & Urea + RTB68 & $5.75 \mathrm{a}$ & $8.90 \mathrm{c}$ & $3.60 \mathrm{a}$ & $1.67 \mathrm{a}$ & $0.88 \mathrm{a}$ & $0.38 \mathrm{a}$ & $0.19 \mathrm{a}$ & $0.13 \mathrm{a}$ & $21.51 \mathrm{a}$ \\
\hline & Urea + NBPT & $0.03 \mathrm{c}$ & $0.07 \mathrm{~d}$ & $0.45 b$ & $0.85 b$ & $0.78 \mathrm{a}$ & $0.77 \mathrm{a}$ & $0.81 \mathrm{a}$ & $0.82 \mathrm{a}$ & $4.58 \mathrm{~b}$ \\
\hline & $0 \%$ nitrogen & $0.01 \mathrm{c}$ & $0.01 \mathrm{~d}$ & $0.00 \mathrm{~b}$ & $0.00 \mathrm{c}$ & $0.01 \mathrm{~b}$ & $0.02 \mathrm{a}$ & $0.00 \mathrm{a}$ & $0.03 \mathrm{a}$ & $0.08 \mathrm{c}$ \\
\hline \multirow{5}{*}{ Ultisol (UL) } & Standard urea & $2.53 \mathrm{a}$ & $11.85 \mathrm{~b}$ & $2.55 \mathrm{a}$ & $0.90 \mathrm{~b}$ & $0.65 b$ & $0.63 b$ & $0.42 \mathrm{~b}$ & $0.29 b$ & $19.82 \mathrm{a}$ \\
\hline & Urea + BZI1 & $2.53 \mathrm{a}$ & $11.34 b$ & $2.55 \mathrm{a}$ & $0.92 b$ & $0.54 b$ & $0.45 b$ & $0.41 \mathrm{~b}$ & $0.27 b$ & $19.02 \mathrm{a}$ \\
\hline & Urea + RTB68 & $3.05 \mathrm{a}$ & $13.38 \mathrm{a}$ & $1.98 \mathrm{a}$ & $0.79 b$ & $0.44 b$ & $0.42 b$ & $0.23 b$ & $0.29 b$ & $20.48 \mathrm{a}$ \\
\hline & Urea + NBPT & $0.05 b$ & $0.03 \mathrm{c}$ & $0.11 b$ & $1.20 \mathrm{a}$ & $1.32 \mathrm{a}$ & $2.88 \mathrm{a}$ & $2.35 \mathrm{a}$ & $1.02 \mathrm{a}$ & $8.96 b$ \\
\hline & $0 \%$ nitrogen & $0.04 \mathrm{~b}$ & $0.01 \mathrm{c}$ & $0.00 \mathrm{~b}$ & $0.01 \mathrm{~b}$ & $0.01 \mathrm{~b}$ & $0.01 \mathrm{~b}$ & $0.00 \mathrm{~b}$ & $0.01 \mathrm{~b}$ & $0.09 \mathrm{c}$ \\
\hline
\end{tabular}

${ }^{(1)}$ Means followed by equal letters, uppercase in the columns and lowercase in the rows, do not differ by Tukey's test, at $5 \%$ probability. 
not corroborate those reported for soils of Brazilian Cerrado, where RTB68 ("compound 18") inhibited soil urease as effectively as NBPT. For that reason, RTB68 was tested in the present study.

For YO, 144 hours after fertilization, there were greater N losses in the urea + BZI1 and the urea + RTB68 treatments than in the urea + NBPT and untreated control, but lower losses than the SU treatment. At 192, 240, 288, and 384 hours, there was no significant difference for ammonia volatilization between the BZI1 and the RTB68 and SU treatments (Table 2). These urease inhibitors may have become ineffective at the advanced stages of urea solubilization and hydrolysis, either because of the urea concentration $(1 \%)$, or of the urea form (coated granules) used. Further studies should evaluate the relative efficacies of these urease inhibitors using other urea concentrations and forms.

From 0-192 hours after fertilization, the urea + NBPT treatment showed ammonia losses similar to those of the untreated control. At 240 and 288 hours, however, the ammonia losses in urea + NBPT were substantially higher than those of the control, and highest at 288 hours (Table 2). NBPT is maximally effective at 3-7 days after application. After that time, it gradually loses its inhibitory activity (Cantarella, 2007). NBPT does not completely inhibit urease but delays the hydrolysis and allows of urea to incorporate into the soil.
For the YO soils, at 336 and 384 hours after fertilization, the ammonia losses were similar in all treatments (Table 2). Therefore, comparatively little hydrolyzable urea remained by that time. The highestammonia losses occurred within five days after fertilization (Duarte et al., 2007; Leguizamón Rojas et al., 2012; Rodrigues et al., 2016).

For the cumulative time period after YO fertilization (384 hours), the greatest ammonia loss occurred in the SU treatment. The second-lowest-ammonia volatilization after the control was measured for the urea + NBPT treatment. Ammonia loss in YO treated with urea + BLI1 (15.37 $\left.\mathrm{kg} \mathrm{ha}^{-1}\right)$ was lower than that in YO treated with urea + RTB68 (17.85 $\left.\mathrm{kg} \mathrm{ha}^{-1}\right)$. Therefore, BZ11 effectively inhibits urease and merits further investigation.

As to time effects, the results for all YO treatments except for the control followed a nonlinear Gaussian model. Peak of ammonia volatilization occurred about 144 hours after fertilization (on the $6^{\text {th }}$ day) for SU, urea + BZI1, and urea + RTB68, however, it occurred at 288 hours for urea + NBPT (Figure 3 ).

The similarity of ammonia volatilization maxima among SU, urea + BZI1, and urea + RTB68 is indicative that, unlike NBPT, the sources SU, BZ11, and RTB68 did not significantly affect volatilization dynamics. In contrast, NBPT delayed the onset of ammonia volatilization in the YOs (Figure 3). In

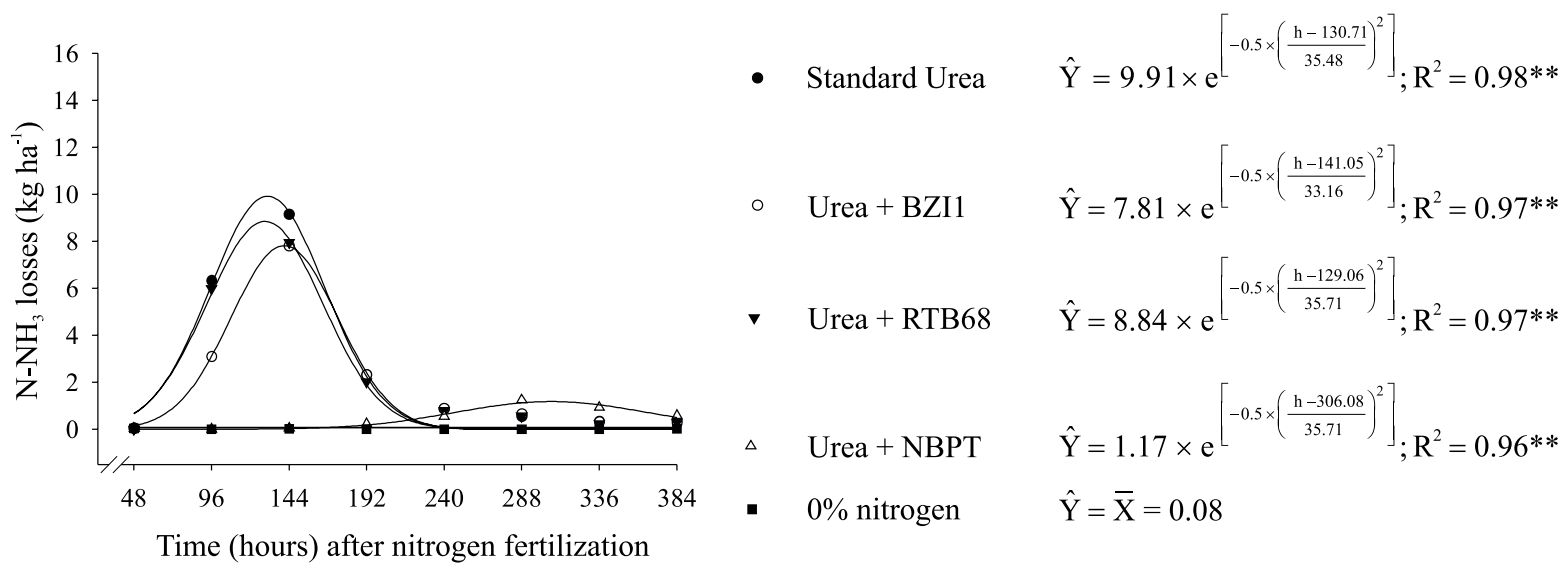

Figure 3. Nitrogen loss by ammonia $\left(\mathrm{NH}_{3}\right)$ volatilization in yellow Oxisol $(\mathrm{YO})$, in the period from zero to 384 hours after $\mathrm{N}$-source applications. 
general, the efficacy of urease inhibitors depends on the same variables that affect ammonia volatilization. In contrast, NBPT delays the peak of ammonia volatilization by forming the urea analog NBPTO, which is hydrolyzed by urease (Scivittaro et al., 2010). This way, NBPT indirectly delays urea hydrolysis, and gives the soil more time to absorb the fertilizer, before it can decompose and volatilize as ammonia.

In the first 48 hours after RO fertilization, urea + BZI1 showed a lower-ammonia volatilization than urea + RTB68 treatment. Ammonia loss from the latter was similar to that of SU. However, ammonia loss from urea + NBPT treatment resembled that of the control (Table 2). At 96 hours after fertilization, the descending order of ammonia loss was urea + BZI1 > $\mathrm{SU}>$ urea $+\mathrm{RTB} 68>$ urea $+\mathrm{NBPT}=$ control.

At 144 and 384 hours after RO fertilization, there were no significant differences for ammonia volatilization among the SU, urea + BZI1, and urea + RTB68 treatments. However, ammonia volatilization in these treatments was higher than that from the urea + NBPT and the control treatments until 192 hours after fertilization. At 240 hour after fertilization, ammonia loss from the urea + NBPT treatment significantly differed from that of the control, but resembled those of the other treatments. The ammonia volatilization rates were similar across all treatments for the last three measurement time points. For the cumulative time period post-fertilization (384 hours), ammonia volatilization did not significantly differ among the urea + BZI1, urea + RTB68, and SU treatments (Table 2).

The high levels of ammonia volatilization, during the first 48 hours and in the accumulated period after fertilization, may be explained by the comparatively high soil-pH (5.8) and low $\mathrm{H}+\mathrm{Al}\left(3.2 \mathrm{cmol}_{\mathrm{c}} \mathrm{dm}^{-3}\right)$ availability in the ROs (Table 1). The high $\mathrm{pH}$ may have also increased urease activity. At $\mathrm{pH}$ 5.2, soil urease activity is $42-44 \%$ of the maximum soil-urease activity measured at $\mathrm{pH} 8.0$ (Longo \& Melo, 2005). Organic matter content in the soil increases the activity of soil microorganisms which, in turn, intensifies the urease production and, by extension, accelerates ammonia volatilization (Knoblauch et al., 2012).

As to the influence of time after fertilization, the RO treatment data fit best in a nonlinear Gaussian model (Figure 4). However, unlike the YOs, a peak of ammonia loss was expected for the ROs, and it occurred 96 hours after fertilization in the urea + BZI1, urea + RTB68, and SU treatments. This soil type had elevated $\mathrm{pH}$ which rapidly induced ammonia volatilization.

At 48 hours after UL fertilization, ammonia volatilization from the urea + BZI1 and urea + RTB68 treatments were similar to that from the standard urea treatment. In contrast, the urea + NBPT treatment and the control showed equal ammonia losses. At 96 hours

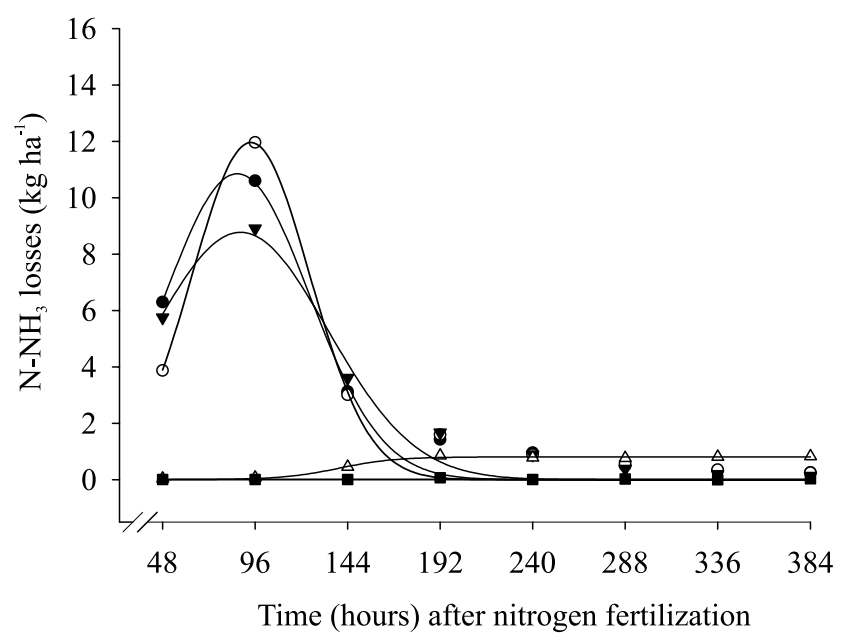

$$
\begin{aligned}
& \text { - Standard Urea } \hat{\mathrm{Y}}=10.84 \times \mathrm{e}^{\left[-0.5 \times\left(\frac{\mathrm{h}-86.73}{37.31}\right)^{2}\right]} ; \mathrm{R}^{2}=0.97 * * \\
& \text { ○ Urea + BZI1 } \hat{\mathrm{Y}}=11.95 \times \mathrm{e}^{\left[-0.5 \times\left(\frac{\mathrm{h}-93.80}{30.54}\right)^{2}\right]} ; \mathrm{R}^{2}=0.96^{* *} \\
& \text { V Urea + RTB68 } \hat{\mathrm{Y}}=8.77 \times \mathrm{e}^{\left[-0.5 \times\left(\frac{\mathrm{h}-88.45}{45.16}\right)^{2}\right]} ; \mathrm{R}^{2}=0.96^{* *} \\
& \Delta \quad \text { Urea + NBPT } \quad \hat{\mathrm{Y}}=\frac{0.80}{{ }^{\left(\frac{\mathrm{h}-139.33)}{14.60}\right)} ; \mathrm{R}^{2}=0.98^{* *}} \\
& \text { - } 0 \% \text { nitrogen } \hat{\mathrm{Y}}=\overline{\mathrm{X}}=0.08
\end{aligned}
$$

Figure 4. Nitrogen loss by ammonia $\left(\mathrm{NH}_{3}\right)$ volatilization in red Oxisol $(\mathrm{RO})$, in the period from zero to 384 hours after $\mathrm{N}$-source applications. 
after treatment, ammonia losses were higher in UL treated with urea + RTB68, urea + BZI1, and SU that they were for the other treatments, and the ammonia loss for the urea + NBPT treatment resembled that of the control (Table 2).

At 144 hours after UL fertilization, ammonia losses did not significantly differ among the SU, urea + BZI1, and urea + RTB68 treatments. Nevertheless, from 192 to 384 hours after fertilization, the urea + NBPT showed the highest-ammonia loss of all treatments. For the cumulative period (384 hours), ammonia losses for the urea + BZI1, urea + RTB68, and SU treatments were significantly higher than those for the urea + NBPT treatment and the control, but the differences were not statistically significant (Table 2).

The low $\mathrm{pH}$ (4.8) of the ULs would decrease ammonia volatilization, especially within the first few hours after fertilization, when there was no sudden $\mathrm{pH}$ increase near the urea granules. However, high-ammonia volatilization is also correlated with soil humidity and temperature (Figure 1 and Table 1). Plinthosols form under limited water percolation (Santos et al., 2013). Consequently, the movement of urea and its derivatives to subsurface layers is impeded, and ammonia volatilization is relatively high. The low-RH and high temperatures during the study period may have intensified evaporation (Tasca et al., 2011), and accelerated ammonia volatilization.

The low-water retention capacity of ULs may have also enhanced evaporation. The field capacity and wilting point of this soil type were 18.37 and $12.08 \%$, respectively. These conditions caused the increase of ammonia losses. In earlier studies using sandy soils, low-water retention capacity accelerated ammonia volatilization (Gioacchini et al., 2002; Oliveira et al., 2014).

As to the effects of time after fertilization on ammonia volatilization, data for the UL treatments were nonlinear, as for the YOs and ROs. For Argiluvic Planosols, the ammonia volatilization peaks occurred near 96 hours after fertilization with SU, urea + BZI1, and urea + RTB68. Ammonia volatilization in UL treated with urea + NBPT peaked after 288 hours (Figure 5). Delay of the ammonia volatilization peak by NBPT was also observed for ROs under field conditions (Silva et al., 2017), and in controlled environments (Soares et al., 2012). NBPT addition to urea decreases the urease activity, delays the urea hydrolysis, and prolongs the life of the amide nitrogen (Marchesan et al., 2013). Therefore, NBPT prevents the increases of $\mathrm{pH}$ and ammonia nitrogen in the fertilizer application zone, and reduces ammonia losses.

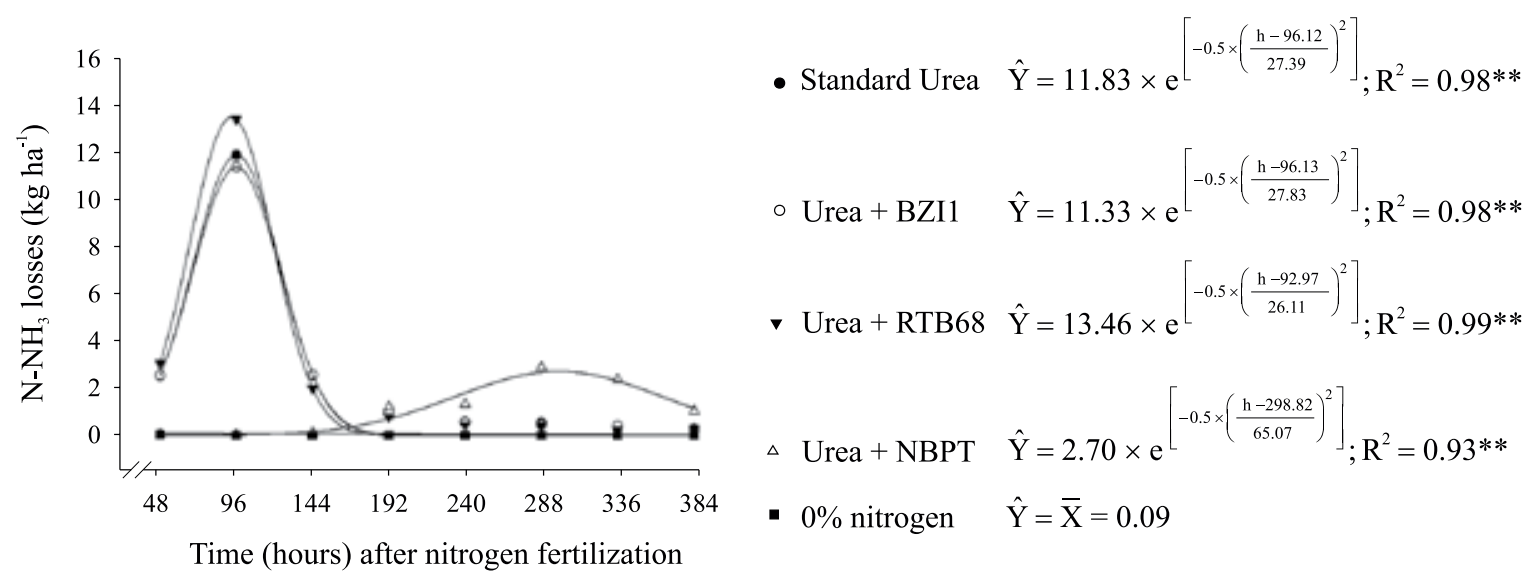

Figure 5. Nitrogen loss by ammonia $\left(\mathrm{NH}_{3}\right)$ volatilization in Ultisol (UL), in the period from zero to 384 hours after N-source applications. 


\section{Conclusions}

1. In yellow Oxisols, BZI1 and RTB68 cause ammonia volatilization decreases by 22 and $10 \%$, respectively, in the soils treated with standard urea.

2. In red Oxisols and Ultisols, BZI1 and RTB68 cause no ammonia volatilization decrease in soils treated with standard urea.

3. BZI1 and RTB68 are not as effective as NBPT at reducing ammonia losses under the edaphoclimatic conditions of the southwestern Amazonia soils.

\section{Acknowledgments}

To Conselho Nacional de Desenvolvimento Científico e Tecnológico $(\mathrm{CNPq}$, protocol No. 458461/2014-8), to Coordenação de Aperfeiçoamento de Pessoal de Nível Superior (Capes), to Network for the Development of Novel Urease Inhibitors (Redniu), and to Coffee Research Network, for their financial support; to Professors Ângelo de Fátima (Department of Chemistry, Universidade Federal de Minas Gerais) and Fernando César de Macedo Júnior (Department of Chemistry, Universidade Estadual de Londrina), for supplying the urease inhibitors.

\section{References}

AFSHAR, R.K.; LIN, R.; MOHAMMED, Y.A.; CHEN, C. Agronomic effects of urease and nitrification inhibitors on ammonia volatilization and nitrogen utilization in a dryland farming system: field and laboratory investigation. Journal of Cleaner Production, v.172, p.4130-4139, 2018. DOI: https://doi.org/10.1016/j.jclepro.2017.01.105.

ARAÚJO, D.P. Síntese e atividades anti-ureolítica e antiproliferativa de benzimidazois e benzotiazois. 2015. 202p. Tese (Doutorado) - Universidade Federal de Minas Gerais, Belo Horizonte.

ARAÚJO, E. da S.; MARSOLA, T.; MIYAZAWA, M.; SOARES, L.H. de B.; URQUIAGA, S.; BODDEY, R.M.; ALVES, B.J.R. Calibração de câmara semiaberta estática para quantificação de amônia volatilizada do solo. Pesquisa Agropecuária Brasileira, v.44, p.769-776, 2009. DOI: https://doi.org/10.1590/S0100204X2009000700018.

BRITO, T.O.; SOUZA, A.X.; MOTA, Y.C.C.; MORAIS, V.S.S.; SOUZA, L.T. de; FÁTIMA, Â. de; MACEDO Jr, F.; MODOLO, L.V. Design, syntheses and evaluation of benzoylthioureas as urease inhibitors of agricultural interest. RSC Advances, v.5, p.44507-44515, 2015. DOI: https://doi.org/10.1039/C5RA07886E.

CANTARELLA, H. Nitrogênio. In: NOVAIS, R.F.; ALVAREZ V., V.H.; BARROS, N.F. de; FONTES, R.L.F.; CANTARUTTI, R.B.;
NEVES, J.C.L. (Ed.). Fertilidade do solo. Viçosa: Sociedade Brasileira de Ciência do Solo, 2007. p.375-470.

COSTA, A.C.S. da; FERREIRA, J.C.; SEIDEL, E.P.; TORMENA, C.A.; PINTRO, J.C. Perdas de nitrogênio por volatilização da amônia em três solos Argilosos tratados com uréia. Acta Scientiarum. Agronomy, v.26, p.467-473, 2004. DOI: https://doi.org/10.4025/actasciagron.v26i4.1809.

DA ROS, C.O.; AITA, C.; GIACOMINI, S.J. Volatilização de amônia com aplicação de uréia na superfície do solo, no sistema plantio direto. Ciência Rural, v.35, p.799-805, 2005. DOI: https://doi.org/10.1590/S0103-84782005000400008.

DUARTE, F.M.; POCOJESKI, E.; SILVA, L.S. da; GRAUPE, F.A.; BRITZKE, D. Perdas de nitrogênio por volatilização de amônia com aplicação de uréia em solo de várzea com diferentes níveis de umidade. Ciência Rural, v.37, p.705-711, 2007. DOI: https://doi.org/10.1590/S0103-84782007000300016.

FRAZÃO, J.J.; SILVA, A.R. da; SILVA, V.L. da; OLIVEIRA, V.A. CORREA, R.S. Fertilizantes nitrogenados de eficiência aumentada e ureia na cultura do milho. Revista Brasileira de Engenharia Agrícola e Ambiental, v.18, p.1262-1267, 2014. DOI: https://doi.org/10.1590/1807-1929/agriambi.v18n12p1262-1267.

GIOACCHINI, P.; NASTRI, A.; MARZADORI, C.; GIOVANNINI, C.; ANTISARI, L.V.; GESSA, C. Influence of urease and nitrification inhibitors on $\mathrm{N}$ losses from soils fertilized with urea. Biology and Fertility Soils, v.36, p.129-135, 2002. DOI: https://doi.org/10.1007/s00374-002-0521-1.

GURGEL, G.C. de S.; FERRARI, A.C.; FONTANA, A.; POLIDORO, J.C.; COELHO, L. de A.M.; ZONTA, E. Volatilização de amônia proveniente de fertilizantes minerais mistos contendo ureia. Pesquisa Agropecuária Brasileira, v.51, p.1686-1694, 2016. DOI: https://doi.org/10.1590/s0100-204x2016000900069.

IFASTAT. Consuption: 2016. Available at: $<$ https://www.ifastat. org/databases/plant-nutrition>. Accessed on: June 82019.

KNOBLAUCH, R.; ERNANI, P.R.; WALKER, T.W.; KRUTZ, L.J.; VARCO, J.J.; GATIBONI, L.C.; DESCHAMPS, F.C. Volatilização de amônia em solos alagados influenciada pela forma de aplicação de ureia. Revista Brasileira de Ciência do Solo, v.36, p.813-821, 2012. DOI: https://doi.org/10.1590/S010006832012000300012 .

LEGUIZAMÓN ROJAS, C.A.; BAYER, C.; FONTOURA, S.M.V.; WEBER, M.A.; VIEIRO, F. Volatilização de amônia da ureia alterada por sistemas de preparo de solo e plantas de cobertura invernais no Centro-Sul do Paraná. Revista Brasileira de Ciência do Solo, v.36, p.261-270, 2012. DOI: https://doi.org/10.1590/S0100-06832012000100027.

LONGO, R.M.; MELO, W.J. de. Hidrólise da uréia em latossolos: efeito da concentração de uréia, temperatura, $\mathrm{pH}$, armazenamento e tempo de incubação. Revista Brasileira de Ciência do Solo, v.29, p.651-657, 2005. DOI: https://doi.org/10.1590/S010006832005000400018 .

MARCHESAN, E.; GROHS, M.; WALTER, M.; SILVA, L.S. da; FORMENTINI, T.C. Agronomic performance of rice to the use of urease inhibitor in two cropping systems. Revista Ciência Agronômica, v.44, p.594-603, 2013. DOI: https://doi.org/10.1590/ S1806-66902013000300023. 
MATHIALAGAN, R.; MANSOR, N.; AL-KHATEEB, B.; MOHAMAD, M.H.; SHAMSUDDIN, M.R. Evaluation of allicin as soil urease inhibitor. Procedia Engineering, v.184, p.449-459, 2017. DOI: https://doi.org/10.1016/j.proeng.2017.04.116.

MODOLO, L.V.; SOUZA, A.X. de; HORTA, L.P.; ARAUJO, D.P.; FÁTIMA, Â. de. An overview on the potential of natural products as ureases inhibitors: A review. Journal of Advanced Research, v.6, p.35-44, 2015. DOI: https://doi.org/10.1016/j.jare.2014.09.001.

OLIVEIRA, J.A. de; STAFANATO, J.B.; GOULART, R. de S.; ZONTA, E.; LIMA, E.; MAZUR, N.; PEREIRA, C.G.; SOUZA, H.N. de; COSTA, F.G.M. Volatilização de amônia proveniente de ureia compactada com enxofre e bentonita, em ambiente controlado. Revista Brasileira de Ciência do Solo, v.38, p.1558-1564, 2014. DOI: https://doi.org/10.1590/S010006832014000500021.

ROCHETTE, P.; ANGERS, D.A.; CHANTIGNY, M.H.; MACDONALD, J.D.; GASSER, M.-O.; BERTRAND, N. Reducing ammonia volatilization in a no-till soil by incorporating urea and pig slurry in shallow bands. Nutrient Cycling Agroecosystem, v.84, p.71-80, 2009. DOI: https://doi.org/10.1007/ s10705-008-9227-6.

RODRIGUES, J. de O.; PARTELLI, F.L.; PIRES, F.R.; OLIOSI, G.; ESPINDULA, M.C.; MONTE, J.A. Volatilização de amônia de ureias protegidas na cultura do cafeeiro Conilon. Coffee Science, v.11, p.530-537, 2016. DOI: https://doi.org/10.25186/cs.v11i4.1167.

SANTOS, H.G. dos; JACOMINE, P.K.T.; ANJOS, L.H.C. dos; OLIVEIRA, V.A. de; LUMBRERAS, J.F.; COELHO, M.R.; ALMEIDA, J.A. de; CUNHA, T.J.F.; OLIVEIRA, J.B. de. Sistema brasileiro de classificação de solos. 3.ed. rev. e atual. Brasília: Embrapa, 2013. 353p.

SANTOSH, P.C.; PANDEYA, S.N.; PATHAK, A.A. Benzimidazole: a versatile chemical entity. International
Journal of Research in Ayurveda and Pharmacy, v.2, p.17261737, 2011.

SCIVITTARO, W.B.; GONÇALVES, D.R.N.; VALE, M.L.C. do; RICORDI, V.G. Perdas de nitrogênio por volatilização de amônia e resposta do arroz irrigado à aplicação de ureia tratada com o inibidor NBPT. Ciência Rural, v.40, p.1283-1289, 2010. DOI: https://doi.org/10.1590/S0103-84782010000600007.

SILVA, D.F. da; PEGORARO, R.F.; MAIA, V.M.; KONDO, M.K.; SOUZA, G.L.O.D. de; MOTA, M.F.C. Volatilização de amônia do solo após doses de ureia com inibidores de urease e de nitrificação na cultura do abacaxi. Revista Ceres, v.64, p.327-335, 2017. DOI: https://doi.org/10.1590/0034-737x201764030014.

SOARES, J.R.; CANTARELlA, H.; MENEGALE, M.L. de C. Ammonia volatilization losses from surface-applied urea with urease and nitrification inhibitors. Soil Biology \& Biochemistry, v.52, p.82-89, 2012. DOI: https://doi.org/10.1016/j. soilbio.2012.04.019.

SOMMER S.G.; SCHJOERRING, J.K.; DENMEAD, O.T. Ammonia emission from mineral fertilizers and fertilized crops. In: SPARKS, D. (Ed.). Advances in Agronomy. Amsterdam: Elsevier, 2004. v.82, p.557-622. DOI: https://doi.org/10.1016/ S0065-2113(03)82008-4.

SUTTON, A.R.; THORNSBERRY, W. Additive containing n-(n-butyl) thiophosphoric triamide for urea-based fertilizer. US Pat. 2007/0157689 A1, Jul. 122007.

TASCA, F.A.; ERNANI, P.R.; ROGERI, D.A.; GATIBONI, L.C.; CASSOL, P.C. Volatilização de amônia do solo após a aplicação de ureia convencional ou com inibidor de urease. Revista Brasileira de Ciência do Solo, v.35, p.493-502, 2011. DOI: https://doi.org/10.1590/S0100-06832011000200018. 